\title{
The surprising "B-side": description of a new foraging tactic for the pearl cichlid, Geophagus brasiliensis, in a coastal stream of the Atlantic Forest
}

\author{
Gabriel Raposo Silva de Souza $^{1 *}{ }^{\mathbb{D}}$, José Sabino ${ }^{2} \mathbb{D}$ \& Domingos Garrone-Neto ${ }^{1,3}$ \\ ${ }^{1}$ Universidade Estadual Paulista, Instituto de Biociências, Programa de Pós-Graduação em Biodiversidade de \\ Ambientes Costeiros, Praça Infante D. Henrique, 11330-900, São Vicente, SP, Brasil \\ ${ }^{2}$ Universidade Anhanguera-Uniderp, Campus UDA, Rua Alexandre Herculano, 1400, 79037-280, \\ Campo Grande, MS, Brasil \\ ${ }^{3}$ Universidade Estadual Paulista, Campus Experimental de Registro, Rua Nelson Brihi Badur, 430, \\ 11900-000, Registro, SP, Brasil \\ *Corresponding author: Gabriel Raposo Silva de Souza, e-mail: gabrielraposo.souza@gmail.com
}

\begin{abstract}
SOUZA, G.R.S., SABINO, J., GARRONE-NETO, D. The surprising "B-side": description of a new foraging tactic for the pearl cichlid, Geophagus brasiliensis, in a coastal stream of the Atlantic Forest. Biota Neotropica. 19(3): e20180702. http://dx.doi.org/10.1590/1676-0611-BN-2018-0702
\end{abstract}

\begin{abstract}
A new foraging tactic for the pearl cichlid, Geophagus brasiliensis, is described from underwater observations performed in a coastal stream of the Atlantic Forest, Southeastern Brazil. Named "shift picking", the foraging tactic involved the manoeuvering of leaves, wood twigs and tree bark present in the substrate, with fish using its mouth to turn objects and uncover macroinvertebrates adhered to the underside of the object being picked ("B-side"). The object-shifting behaviour is rarely reported for fish and the present description seems to be the first record for a freshwater species of South America.
\end{abstract}

Keywords: foraging behaviour; fish ecology; naturalistic studies; Cichlidae; Atlantic Forest.

\section{O surpreendente "lado-B": descrição de uma nova tática de forrageamento para o acará, Geophagus brasiliensis, em um riacho costeiro da Mata Atlântica}

\begin{abstract}
Resumo: Uma nova tática de forrageamento do acará, Geophagus brasiliensis, é descrita a partir de observações subaquáticas realizadas em um riacho costeiro da Mata Atlântica, Sudeste do Brasil. Chamada de "virar para pegar", a tática de forrageamento envolve o movimento de folhas, galhos e cascas de árvores presentes no substrato, com os peixes usando a boca para virar objetos e expor macroinvertebrados aderidos à parte de baixo dos objetos explorados ("lado B"). O comportamento de mover objetos é raramente relatado e o presente trabalho parece ser o primeiro registro para uma espécie de água doce da América do Sul.

Palavras-chave: comportamento de forrageamento; ecologia de peixes; estudos naturalísticos; Cichlidae; Mata Atlântica.
\end{abstract}

\section{Introduction}

The pearl cichlid, Geophagus brasiliensis (Quoy \& Gaimard, 1824) (Perciformes, Cichlidae), is widely distributed along the coastal drainages of eastern and southern Brazil and Uruguay (Kullander 2003). This species inhabits the lentic habitats and shallow waters of rivers, streams, lakes, reservoirs and even brackish environments (Nunes et al. 2014). Presenting diurnal activity and visual orientation (Sabino \& Castro 1990), G. brasiliensis feeds on a wide variety of items, preferring benthic resources such as molluscs, vascular plants, crustaceans, fish scales, insects, among others (Nomura \& Carvalho 1972, Sabino \& Castro 1990, Abelha \& Goulart 2004). Its high trophic plasticity and opportunism allow the exploitation of different resources and this species is usually classified as an omnivore (Sabino \& Castro
1990, Arcifa \& Meschiatti 1993, Dias et al. 2004, Moraes et al. 2004, Gomiero \& Braga 2008, Bastos et al. 2011), although differences in prey availability across study sites and conceptual approaches may lead $G$. brasiliensis to a variety of trophic preferences that include detritivory (e.g., Meschiatti 1995), insectivory (e.g., Ribeiro et al. 2014) or even benthivory (e.g., Nunes et al. 2014). However, the diversified foraging behaviour known for G. brasiliensis is usually based and inferred from the analysis of stomach contents, thus limiting the understanding of how occurs the ingestion of prey hidden under structures or adhered to objects such as leaves, wood twigs, and tree barks.

Few studies have provided information on the foraging behaviour of G. brasiliensis in the wild. Sabino \& Castro (1990) observed this species in feeding activity during the day, obtaining food using the foraging tactic named "picking up substrate and sorting prey" (sensu Keenleyside 
1979), that comprises the combination of the protrusion of the upper jaw with the opening of the operculum to separate the food items from the debris. This foraging behaviour in cichlids has been recently described as "sediment sifting", with several analyses of morphology and evolutionary process related to this strategy for the South American cichlids (see López-Fernández et al. 2012, 2014). Through this tactic, Sabino \& Castro (1990) suggested that G. brasiliensis was able to excavate the sediment and feed on prey hidden in the substrate. Uieda (1995) also observed the use of this foraging tactic by G. brasiliensis and added "picking at relatively small prey" (sensu Keenleyside 1979) to the role of foraging tactics displayed by the species. This foraging tactic allowed the species to catch prey on the bottom rocks and classified $G$. brasiliensis as having an intermediate niche amplitude when compared to other two bottom omnivorous fishes which fed on insects (Uieda 1995). After that, no study attempted to refine the knowledge about the feeding behaviour of $G$. brasiliensis through a naturalistic approach, which highlights the need of studies to better understand how prey is selected and captured.

In this study we report a new foraging tactic for G. brasiliensis, presumably focusing on macroinvertebrates hidden under objects. We confronted our findings with the literature on the diet of the species, discussing how its morphological and behavioural characteristics can influence the capture of prey. Additionally, we searched for information about the behaviour of moving objects among freshwater fish, since this tactic seems to be rarely described or even uncommon worldwide.

\section{Material and Methods}

The study was performed in the Rio das Minas, a coastal stream located in Cananeia, a municipality of Southeastern Brazil that comprises a biodiversity hotspot with the largest remaining fragment of the Atlantic Forest ecosystem in the country (about 2459'35'S, 4807'31' W).

The underwater observations were made at day hours (10h00min14h00min) while snorkelling ( $c f$. Sabino 1999), during the dry season between April to August 2018. "Ad libitum" and "behaviour" sampling rules (Martin \& Bateson 1986) were used throughout the observational sessions, mostly recorded on a plastic slate. Additionally, digital photographs and video records were taken to check visual observations, based on the methods presented by Sazima (1986) and Sabino (1999). Size estimates (total length in cm, TL) for $G$. brasiliensis were calibrated against objects of known size. Fish identification was done in situ during the underwater observations (following Oyakawa et al. 2006 and Oyakawa \& Menezes 2011), without the need to capture the animals.

\section{Results}

During approximately ten hours of underwater observations, mostly at depths of 0.8 to $2.5 \mathrm{~m}, 19$ individuals of $G$. brasiliensis $(8-25 \mathrm{~cm}$ TL) were observed moving leaves, wood twigs and fragments of tree bark to uncover prey adhered to the underside ("B-side") of the object being picked (see Supplementary Material - Video). Named here as "shift picking", this foraging tactic started when fish were swimming under organic substrate until they encountered some object (mainly leaves). To turn it, the fish approach the object horizontally, pushing it forward with the mouth while performing movements with the caudal and pectoral fins (Figure 1a). Such movements were apparently stronger when objects were larger in relation to fish size, with fish moving the caudal fin faster than was observed while moving smallest objects. Once turned, the object had the "B-side" explored by the fish; in this case, with fish biting items sighted at the surface of the object, with the body horizontally positioned in relation to the substrate or slightly inclined forward (Figure 1b). Between a bite and another, the fish moved away from the object, swimming backwards and moving the head to the side, in an apparent attempt to spot other prey. The number of bites ranged from one to three per object, with fish performing buccal and opercular movements as described by Sabino \& Castro (1990) and Drucker \& Jensen (1991) while consuming the prey. The time spent by the fish to turn and examine on each object was about 30 seconds. There was no relationship between the use of "shift picking" and the current flow; however, the foraging tactic was only observed in fish present in lentic environments, such as mesohabitats formed by pools. Although sighted during the observation sessions in the shallower areas of the pools, individuals smaller than $8 \mathrm{~cm}$ TL were not observed using this foraging tactic.

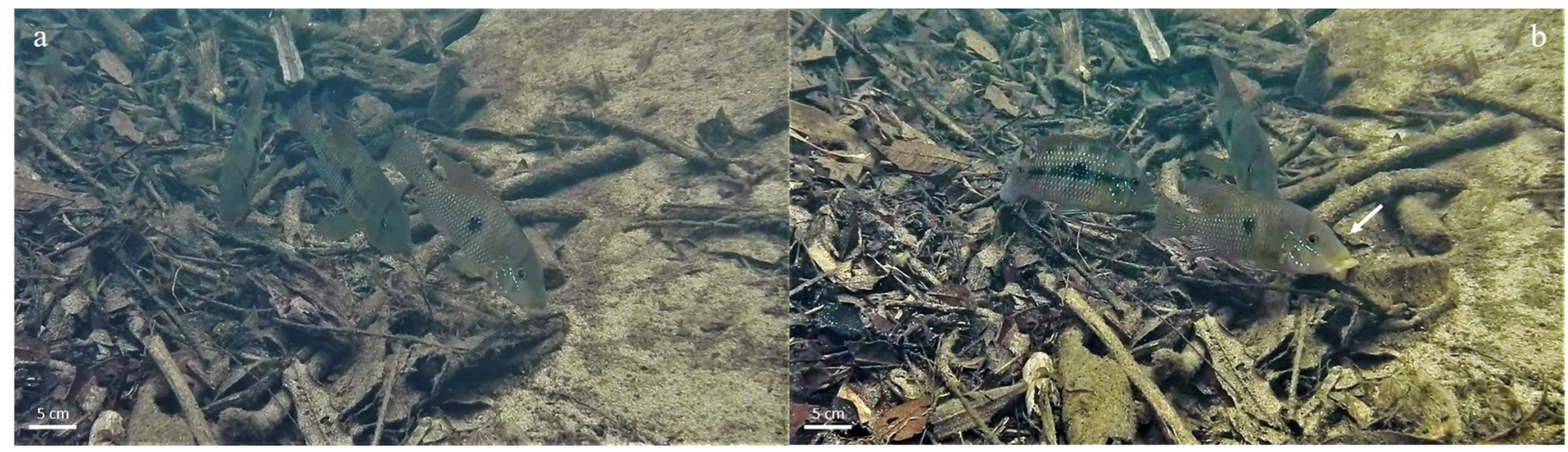

Figure 1. Geophagus brasiliensis performing "shift picking". The individual on the right side approaches the object (tree bark), turning it with the mouth (a) to pick up a hidden prey (white arrow) (b). 


\section{Discussion}

Neotropical communities of freshwater fish are characteristically rich in species and present complex interrelationships between its components (Lowe-McConnell 1987). Among these relationships, feeding strategies are known to involve morphological and behavioural specializations, such as cleaning, mimicry and social foraging associations and seem to involve several species of fish and invertebrates (see Sazima 1986 and Sabino et al. 2016 for overviews). However, the manoeuvering of object by freshwater fish (named as "object-shifting behaviour") seems to be uncommon and is poorly documented in the literature.

Available records show that some North American species of the genus Percina (family Percinidae) use their conical snout to flip gravel and feed on exposed invertebrates that may be unavailable to other benthic fish (Rosenberger \& Angermeier 2003). According to Burkhead (1983) and Jenkins \& Burkhead (1993), this behaviour seems to be associated with environments where the substrate is loosely embedded and should not be displayed by young individuals of Percina spp. (which live in shallower areas, over sandy substrate). Other records describe the "object-shifting behaviour" for cichlids in Central America (Wisenden et al. 1995 and references therein) and for the coal grunter, Hephaestus carbo (Ogilby \& McCulloch, 1916) (Terapontidae), in northern Queensland, Australia (Ebner et al. 2018).

In the first case, the cichlids Amatitlania nigrofasciata (Günther, 1867), Cribroheros alfari (Meek, 1907) and Cryptoheros panamensis (Meek \& Hildebrand, 1913) were considered as occasional users of two foraging tactics, "fin digging" and "leaf lifting", in an attempt to increase the availability of food for their fry (Wisenden et al. 1995). Sometimes non-breeding individuals of these species occasionally fin dig and leaf lift while foraging for themselves, but both acts appear to be performed more often by breeding pairs, especially when their young are free-swimming fry (Wisenden et al. 1995). In the second case, small $(<5 \mathrm{~cm} \mathrm{TL})$ to medium-sized individuals $(5-15 \mathrm{~cm} \mathrm{TL})$ of H. carbo were observed using the mouth, snout and even the nape to lift, flip and roll benthic objects to feed on benthic macroinvertebrates (Ebner et al. 2018). Larger individuals (15-20 cm TL) of $H$. carbo were not observed performing "object-shifting behaviour", which may reflect the ontogenetic changes in the diet of the species, from the ingestion of benthic macroinvertebrates by juveniles to crustaceans, fishes and insects caught in the surface by adults, and/or be related to an effect of data collection (e.g., observer effect) (Ebner et al. 2018).

For G. brasiliensis, even though it has been described as an omnivore which consumes a wide range of food items, an analysis of the trophic interactions between the species and the community of benthic macroinvertebrates showed an important contribution of Chironomidae larvae (Diptera) in its diet when compared to other items, especially to debris (Nunes et al. 2014). These findings also suggested that the ingestion of debris and organic matter by G. brasiliensis seems to be more related to the selection of macroinvertebrates present in the substrate than to the intentional consumption of this type of item as cited by several studies (Nunes et al. 2014). Our observations of "object-shift behaviour" for $G$. brasiliensis agree with these findings and can help explain the high selectivity of macroinvertebrates (presumably insect larvae such as Chironomidae) by the species.
The non-observation of "shift picking" among individuals of smaller size $(<8 \mathrm{~cm} \mathrm{TL})$ may reflect ontogenetic changes in the diet and habitat utilization of $G$. brasiliensis. In the study area, individuals of smaller size preferentially inhabit shallower areas (0.5-0.8 m depth) with predominantly sandy and muddy bottoms, while medium and large-sized individuals (8-25 cm TL) prefer the deeper areas (0.8 to $2.5 \mathrm{~m}$ depth) where the foliage covers the bottom (G. R. S. Souza pers. obs.). Thus, the accumulation of allochthonous material allows the concentration of detritivorous invertebrates and may help predict the adoption of "shift picking" by G. brasiliensis in coastal streams. The description of this new foraging tactic highlights the importance of naturalistic studies for a better understanding of the way of life of fish in nature and reinforces the importance of the connection between fish and riparian forests in tropical environments. The "object-shifting behaviour" is still rarely reported in the literature for fish and the present description seems to be the first record for a freshwater species in South America.

\section{Supplementary Material}

The following online material is available for this article: Video

\section{Acknowledgments}

We thank Instituto Linha D'Água for the financial support, in the context of the project "Peixes do Lagamar" (facebook.com/ peixesdolagamar). We are also thankful for the field support of Manuela A. N. Sales, Eduardo O. Santinelli, Bruno Ogata and members of the traditional communities of Mandira and Rio das Minas, Cananeia - SP. This study was financed in part by the Coordenação de Aperfeiçoamento de Pessoal de Nível Superior - Brasil (CAPES) - Finance Code 001. We express our gratitude to the anonymous referees for providing valuable suggestions.

\section{Author Contributions}

Gabriel Raposo Silva de Souza: Substantial contributions to the conception and design of the work, contribution to data collection, contribution in the analysis and interpretation of data and contribution in the writing of the work.

José Sabino: Contribution in the analysis and interpretation of data, contribution in the writing of the work and contribution in critical review adding intellectual content.

Domingos Garrone-Neto: Substantial contribution to the idea and design of the work, contribution in analysis and interpretation of data, contribution in the writing of the work and contribution in critical review adding intellectual content.

\section{Conflicts of interest}

The authors declare that they have no conflict of interest related to the publication of this manuscript. 


\section{References}

ABELHA, M.C. \& GOULART, E. 2004. Oportunismo trófico de Geophagus brasiliensis (Quoy \& Gaimard, 1824) (Osteichthyes, Cichlidae) no reservatório de Capivari, Estado do Paraná, Brasil. Acta Sci Biol Sci 26(1): $37-45$.

ARCIFA, M.S. \& MESCHIATTI, A.J. 1993. Distribution and feeding ecology of fishes in a Brazilian Reservoir: Lake Monte Alegre. Interciencia 18: 302-313.

BASTOS, R.F., CONDINI, M.V., VARELA-JUNIOR, A.S. \& GARCIA, A.M. 2011. Diet and food consumption of the pearl cichlid Geophagus brasiliensis (Teleostei: Cichlidae): relationships with gender and sexual maturity. Neotrop Ichthyol 9(4): 825-830.

BURKHEAD, N.M. 1983. Ecological studies of two potentially threatened fishes (the orangefin madtom, Noturus gilberti, and the Roanoke logperch, Percina rex) endemic to the Roanoke River drainage. Final Report to the US Army Corps of Engineers, Wilmington, NC.

DIAS, A.C.M.L., BRANCO, C.W.C. \& LOPES, V.G. 2005. Estudo da dieta natural de peixes no reservatório de Ribeirão das Lajes, Rio de Janeiro, Brasil. Acta Sci Biol Sci 27: 355-364.

DRUCKER, E.G. \& JENSEN, J.S. 1991. Functional analysis of a specialized prey processing behavior: winnowing by surfperches (Teleostei: Embiotocidae). J Morphol 210(3): 267-287.

EBNER, B.C., DONALDSON, J.A. \& STARRS, D. 2018. Coal grunters shift benthic objects to access macroinvertebrates in a headwater stream. Paci Conserv Biol. doi 10.1071/PC18042.

GOMIERO, L.M. \& BRAGA, F.M.S. 2008. Feeding habits of the ichthyofauna in a protected area in the state of São Paulo, southeastern Brazil. Biota Neotrop 8: 1-8. http://www.biotaneotropica.org.br/v8n1/en/ abstract?article+bn00608012008 (último acesso em 19/11/2018).

JENKINS, R.E. \& BURKHEAD, N.M. 1993. Freshwater Fishes of Virginia. American Fisheries Society, Bethesda, MD.

KEENLEYSIDE, M.H.A. 1979. Diversity and Adaptation in Fish Behaviour. Springer, Berlin.

KULLANDER, S.O. 2003. Family Cichlidae (Cichlids). In: Checklist of the Freshwater Fishes of South and Central America (R.R. Reis, S.O. Kullander \& C.J.Jr. Ferraris, eds). Edipucrs, Porto Alegre, p.605-654.

LÓPEZ-FERNÁNDEZ, H., WINEMILLER, K.O., MONTAÑA, C. \& HONEYCUTT, R.L. 2012. Diet-morphology correlations in the radiation of South American geophagine cichlids (Perciformes: Cichlidae: Cichlinae). Plos One 7(4): e33997.

LÓPEZ-FERNÁNDEZ, H., ARBOUR, J., WILLIS, S., WATKINS, C., HONEYCUTT, R.L. \& WINEMILLER, K.O. 2014. Morphology and efficiency of a specialized foraging behavior, sediment sifting, in neotropical cichlid fishes. Plos One 9(3): e89832.
LOWE-MCCONNELL, R.H. 1987. Ecological studies in tropical fish communities. Cambridge University Press, New York.

MARTIN, P. \& BATESON, P. 1986. Measuring Behaviour - an Introductory Guide. Cambridge University Press, New York.

MESCHIATTI, A.J. 1995. Alimentação da comunidade de peixes de uma lagoa marginal do rio Mogi-Guaçu, SP. Acta Limnol Bras 7: 115-137.

MORAES, M.F.P.G., BARBOLA, I.V. \& DUBOC, L.F. 2004. Feeding habits and morphometry of digestive tracts of Geophagus brasiliensis (Osteichthyes, Cichlidae), in a lagoon of high Tibagi River, Paraná state, Brazil. Publ UEPG Ci Biol Saúde 10(1): 37-45.

NOMURA, H. \& CARVALHO, S.C. 1972. Biologia e número de rastros do acará, Geophagus brasiliensis (Pisces, Cichlidae). Rev Bras Biol 32: 169-176.

NUNES, M.V., ROCHA, O. \& VERANI, J.R. 2014. Trophic interactions between the fish Geophagus brasiliensis (Cichlidae) and the benthic macroinvertebrate community. Stud Neotrop Fauna Environ 49(1): 11-17.

OYAKAWA, O.T., AKAMA, A., MAUTARI, K.C. \& NOLASCO, J.C. 2006. Peixes de riachos da Mata Atlântica nas Unidades de Conservação do Vale do Rio Ribeira de Iguape no Estado de São Paulo. Neotropica, São Paulo.

OYAKAWA, O.T. \& MENEZES, N.A. 2011. Checklist dos peixes de água doce do Estado de São Paulo, Brasil. Biota Neotrop 11(1a): 19-31 http://www. biotaneotropica.org.br/v11n1a/en/abstract?inventory+bn0021101a2011 (último acesso em 19/11/2018).

RIBEIRO, A.R., BIAGIONI, R.C. \& SMITH, W.S. 2014. Estudo da dieta natural da ictiofauna de um reservatório centenário, São Paulo, Brasil. Iheringia, Sér Zool 104(4): 404-412.

ROSENBERGER, A. \& ANGERMEIER, P.L. 2003. Ontogenetic shifts in habitat use by the endangered Roanoke logperch (Percina rex). Freshwat Biol 48: 1563-1577.

SABINO, J. \& CASTRO, R.M.C. 1990. Alimentação, período de atividade e distribuição espacial dos peixes de um riacho da Floresta Atlântica (sudeste do Brasil). Rev Bras Biol 50: 23-36.

SABINO, J. (1999) Comportamento de peixes em riachos: métodos de estudos para uma abordagem naturalística. Oecol Bras 6(1): 6.

SABINO, J., ANDRADE, L.P., SAZIMA, I., TERESA, F.B., FLOETER, S.R., SAZIMA, C. \& BONALDO, R.M. 2017. Following fish feeding associations in marine and freshwater habitats. Mar Freshwat Res 68(2): 381-387.

SAZIMA, I. 1986. Similarities in feeding behaviour between some marine and freshwater fishes in two tropical communities. J Fish Biol 29: 53-65.

UIEDA, V.S. 1995. Comunidade de peixes de um riacho litorâneo: composição, habitat e hábitos. Tese de doutorado, Universidade Estadual de Campinas, Campinas.

WISENDEN, B.D., LANFRANCONI-IZAWA, T.L. \& KEENLEYSIDE, M.H. 1995. Fin digging and leaf lifting by the convict cichlid, Cichlasoma nigrofasciatum: examples of parental food provisioning. Anim Behav 49(3): 623-631. 